\title{
MODERASI PENGAKUAN PROFESIONAL PADA HUBUNGAN PEMAHAMAN KODE ETIK PROFESI DAN PEMILIHAN KARIR SEBAGAI AKUNTAN
}

\author{
Putu Purnama Dewia, ${ }^{*}$, Ni Putu Ayu Dea Novi Yantib \\ a,bUniversitas Pendidikan Nasional, Jalan Bedugul Nomor 39 Sidakarya \\ Denpasar, Bali, Indonesia \\ *(purnamadewi@undiknas.ac.id)
}

\begin{abstract}
ABSTRAK
Penelitian ini bertujuan untuk menguji pengaruh pemahaman mahasiswa mengenai kode etik profesi terhadap pemilihan karir sebagai akuntan dan untuk mengetahui pengaruh pengakuan profesional dalam memoderasi hubungan pemahaman kode etik profesi tehadap pemilihan karir sebagai akuntan. Populasi dalam penelitian ini adalah mahasiswa akuntansi yang sedang mengikuti pendidikan pasca sarjana magister akuntansi. Jumlah sampel yang digunakan sebanyak 95 orang dengan tehnik pengumpulan data melalui penyebaran kuesioner kepada responden. Uji analisis yang digunakan adalah regresi moderasi. Hasil analisis menunjukkan bahwa pemahaman mahasiswa akuntansi yang sedang menempuh pendidikan pasca sarjana magister akuntan mengenai kode etik profesi berpengaruh positif terhadap pemilihan karir sebagai akuntan dan pengakuan profesional mampu memperkuat hubungan pemahaman mahasiswa terhadap kode etik akuntan dan pemilihan karir sebagai akuntan.
\end{abstract}

Kata kunci: pemilihan karir, pemahaman kode etik profesi, pengakuan profesional

\begin{abstract}
This study aims to determine the effect of students' understanding of the professional code of ethics towards career selection as an accountant and to determine the effect of professional recognition in moderating the understanding of professional ethics code to the selection of careers as accountants. The populations in this study are accounting students who are studying post graduate master of accounting. The number of samples used counted 95 people with data collection techniques through the distribution of questionnaires to respondents. The analysis test used is moderation regression. The result of the analysis shows that the understanding of accounting students who are studying the post graduate master of accounting on professional code of ethics has a positive effect on career selection as an accountant and professional recognition is able to moderate the understanding of the students' understanding of the accountant's ethics code and career selection as an accountant.
\end{abstract}

Keywords: career selection, understanding of professional code of ethics, professional recognition 


\section{PENDAHULUAN}

Kode etik profesi merupakan suatu aturan yang ditetapkan secara bersama-sama untuk mencapai keseragaman ukuran perilaku. Dan salah satu upaya dari suatu asosiasi profesi untuk menjaga integritas profesi tersebut agar mampu menghadapi tekanan yang dapat muncul dari dirinya sendiri atau pihak luar. Profesi akuntan hanya bisa dijaga jika seorang akuntan berpedoman pada kode etik, standar dan moralitas. Kepatuhan terhadap kode etik, sama seperti semua standar dalam masyarakat terbuka.

Berbagai kasus pelanggaran yang sempat terjadi menyebabkan hilangnya kepercayaan publik atas profesionalisme jasa akuntan publik. Kegagalan atau penyimpangan audit yang dilakukan oleh auditor, mendorong diperlukannya suatu kemampuan auditor untuk mempertimbangkan etika dan perilaku dalam pelaksanaan audit. Selain itu juga diperlukan adanya pemahaman dari akuntan mengenai pentingnya kode etik profesi akuntan, karena etika memiliki peranan penting dalam perkembangan profesi akuntan di Indonesia. Pelanggaran akuntan lebih mengarah pada pelanggaran etika, seperti akuntan yang melakukan rekayasa terhadap laporan auditnya (Halim, 2015).
Seperti kasus yang terjadi di PT Kereta Api Indonesia yang melibatkan auditor eksternal yaitu kantor akuntan publik S. Manan \& Assosiates telah melakukan kecurangan dalam penyajian laporan keuangan dimana seharusnya PT Kereta Api Indonesia menderita kerugian namun dilaporkan mendapat laba. Selain itu, di Amerika Serikat juga terjadi kasus pelanggaran etika Enron dimana KAP Arthur Andreson yang ditunjuk sebagai auditor laporaan keuangan memanipulasi laporan keuangan Enron Crop, agar laporan keuangan mereka terlihat lebih bagus di mata investor.

Dunia pendidikan akuntansi juga mempunyai peranan yang sangat besar terhadap pemahaman informasi mengenai kode etik seorang akuntan. Dalam menjalankan pendidikan akuntansi, calon-calon akuntan akan diberikan pengetahuan mengenai ilmu akuntansi dan pemahaman akan pentingnya penerapan kode etik dalam melaksanakan tugas audit yang akan menunjukkan tingkat profesionalisme dari akuntan tersebut. Melalui pemahaman yang baik mengenai kode etik akuntansi mampu medorong sikap profesionalisme seorang akuntan dalam menjalankan tugas-tugas auditnya. 
Dalam pemilihan karir sebagai akuntan terdapat beberapa faktor yang menjadi pertimbangan salah satunya adalah pengakuan profesional. Pengakuan profesional meliputi hal-hal yang berhubungan dengan pengakuan terhadap prestasi. Pengakuan profesional ini dapat juga dikategorikan sebagai penghargaan yang tidak berwujud finansial (Stolle dalam Aprilya, 2011). Berdasarkan latar belakang tersebut, penulis tertarik untuk melakukan penelitian mengenai moderasi pengakuan profesional pada hubungan pemahaman mahasiswa mengenai kode etik profesi dan pemilihan karir sebagai akuntan.

\section{TELAAH LITERATUR DAN PERUMUSAN HIPOTESIS}

\section{Teori Kepribadian}

Personality

(kepribadian)

didefinisikan oleh Salvatore Maddi (2001) dalam Noviyanti (2008) sebagai karakteristik dan kecenderungan seseorang yang bersifat konsisten yang menentukan perilaku psikologi seseorang seperti cara berpikir, berperasaan, dan bertindak. Sedangkan Allport (1960) mendefinisikan kepribadian sebagai organisasi organik dalam individu yang memiliki sistem psikologis yang menentukan penyesuaian uniknya terhadap lingkungannya. Jadi, kepribadian merupakan cara-cara unik yang ditempuh individu dalam bereaksi terhadap dan berinteraksi dengan orang lain.

Teori kepribadian menggambarkan konsistensi karakteristik seseorang dalam berpikir dan bertindak. Jika dikaitkan dengan konsep penelitian ini, teori kepribadian dapat memberikan acuan bahwa ketika seorang auditor memiliki pemahaman yang baik mengenai etika profesi, kecenderungan yang terjadi adalah akan timbul keinginan untuk memilih profesi dalam bidang ilmu yang ditekuninya itu. Dalam mempertimbangkan pilihan tersebut, beberapa hal dapat menjadi pendorong pada saat menentukan keputusan seperti salah satunya yaitu pengakuan profesional.

\section{Teori Etika}

Bertens dalam Januarti (2011) mengemukan bahwa teori etika merupakan teori yang membantu manusia untuk mengambil keputusan moral dan menyediakan pembuktian mengenai fakta yang mendukung mengenai pengambilan keputusan. Bertens menyebutkan bahwa teori etika dapat membantu proses pengambilan keputusan yang berhubungan dengan moral dan justifikasi terhadap 
keputusan tersebut. Menurut Duska (2003), teori etika dikembangkan dalam tiga bagian, yaitu:

1) Utilitarianism Theory

Teori ini membahas mengenai optimalisasi pengambilan keputusan individu untuk memaksimumkan manfaat dan meminimalkan dampak negatif. Terdapat dua jenis utilitarisme, yaitu:

a. Act Utilitarisme yaitu perbuatan yang bermanfaat untuk banyak orang.

b. Rule Utilitarisme yaitu aturan moral yang diterima oleh masyarakat luas.

2) Deontologi Theory

Teori etika ini membahas mengenai kewajiban individu untuk memberikan hak kepada orang lain, sehingga dasar untuk menilai baik atau buruk suatu hal harus didasarkan pada kewajiban, bukan konsekuensi perbuatan.

3) Virtue Theory

Teori ini menjelaskan disposisi watak seseorang yang memungkinkan untuk bertingkah laku baik secara moral. Ada dua jenis virtue theory, yaitu:

- Pelaku bisnis individual, seperti: kejujuran, fairness, kepercayaan dan keuletan.
- Taraf perusahaan, seperti: kemarahan, loyalitas, kehormatan, rasa malu yang dimiliki oleh manajer dan karyawan.

\section{Pengertian Etika dan Etika Profesi}

Etika merupakan peraturanperaturan yang dirancang untuk mempertahankan suatu profesi pada tingkat yang bermartabat, mengarahkan anggota profesi dalam hubungannya satu dengan yang lain, dan memastikan kepada publik bahwa profesi akan mempertahankan tingkat kinerja yang tinggi. Etika adalah ilmu yang mempelajari tentang ukuran baik dan buruk tingkah laku manusia dalam mencari keterangan yang benar. Dengan kata lain, etika adalah nilai-nilai dan norma-norma susila yang menjadi pegangan bagi seseorang atau suatu kelompok masyarakat dalam mengukur tingkah lakunya. Tujuan etika adalah agar setiap manusia mengetahui dan menjalankan perilaku yang baik, yang penting bagi dirinya, orang lain, masyarakat, bangsa, dan negara, terutama bagi Tuhan Yang Maha Esa.

Etika profesional lebih luas dari prinsip-prinsip moral. Etika tersebut mencakup prinsip perilaku untuk orang-orang profesional yang dirancang baik untuk tujuan praktis 
maupun untuk tujuan idealistis. Oleh karena kode etik profesional antara lain dirancang untuk mendorong perilaku ideal, maka kode etik harus realistis dan dapat dilaksanakan. Maultz dan Sharaf dalam Nurlan (2011), mengatakan bahwa etika profesional adalah aplikasi khusus dari etika sosial. Etika sosial menekankan bahwa ada pedoman tertentu yang menjadi dasar bagi seseorang untuk berperilaku. Pengetahuan akan hasil akhir dari tindakannya terhadap dirinya dan orang lain, kewaspadaan akan tuntutan masyarakat dimana dia tinggal, penghargaan akan aturan agama, penerimaan tugas, kewajiban untuk melakukan hal yang dia inginkan diperbuat orang lain terhadap dirinya sepanjang waktu, dan pengenalan akan norma perilaku etis di masyarakat tempat seseorang hidup, semuanya membantu seseorang untuk mencapai tingkat perilaku etis yang tinggi.

\section{Pengertian Kode Etik Ikatan Akuntan Indonesia}

Kode etik ikatan akuntan merupakan suatu prinsip moral dan pelaksanaan aturan yang memberi pedoman dalam berhubungan dengan klien, masyarakat, sesama rekan akuntan dan pihak-pihak yang berkepentingan lainnya. Bagi akuntan publik sangatlah penting untuk meyakinkan kualitas jasa profesionalnya baik kepada klien, masyarakat atau pemakai jasa profesi lainnya. Agar masyarakat percaya bahwa pekerjaan akuntan publik dikerjakan dengan baik maka profesi akuntan publik perlu meningkatkan mutu pemeriksaannya dan melaksanakan tugasnya dengan cermat dan seksama. Kode etik ikatan akuntan ini diharapkan dapat membantu para akuntan publik untuk mencapai mutu pemeriksaan pada tingkat yang diharapkan, kode etik juga dapat dijadikan panduan dan aturan terhadap seluruh anggota baik yang bekerja sebagai akuntan publik, bekerja di lingkungan dunia usaha bekerja di instansi pemerintahan, maupun di lingkungan dunia pendidikan dalam memenuhi tanggung jawab profesionalnya.

Kode etik Ikatan Akuntan Indonesia pertama kali dirumuskan dan disahkan pada kongres IAI tahun 1973. Dalam perkembangannya, kode etik tersebut mengalami beberapa kali perubahan yaitu kongres IAI tahun 1981, kongres IAI tahun 1986, kongres IAI tahun 1990, kongres IAI tahun 1994, dan yang terakhir adalah kongres IAI tahun 1998. Kode etik IAI yang berlaku saat ini adalah kode etik IAI yang disahkan dalam kongres IAI VIII tahun 1998 di Jakarta. 
Prinsip Etika

Prinsip etika memberikan kerangka dasar bagi aturan etika yang mengatur pelaksanaan pemberian jasa profesional oleh anggota. Prinsip Etika bukan merupakan standar yang bisa dipaksakan pelaksaannya, sedangkan aturan etika merupakan standar minimum yang telah diterima dan bisa dipaksakan pelaksaannya. (Halim Abdul, 2015:33)

Menurut (Mulyadi, 2014) dalam Kode Etik Akuntan Indonesia terdapat delapan Prisip etika sebagai berikut

1) Prinsip Tanggung Jawab Profesi

Anggota mempunyai tanggung jawab kepada semua pemakai jasa profesional mereka.

2) Prinsip Kepentingan Publik

Profesi akuntan memegang peranan terhadap kepentingan masyarakat dan institusi yang dilayani anggota secara keseluruhan.

3) Prinsip Integritas

Integritas mengharuskan seorang anggota untuk bersikap jujur dan berterus terang tanpa harus mengorbankan rahasia penerima jasa.

4) Prinsip Objektivitas

Objektivitas adalah suatu kualitas yang memberikan nilai jasa yang diberikan anggota.
5) Prinsip Kompetensi dan Kehatihatian Profesional

Kehati-hatian profesional mengharuskan anggota untuk memenuhi tanggung jawab profesionalnya dengan kompetensi dan ketekunan.

6) Prinsip Kerahasiaan

Kerahasiaan harus dijaga oleh anggota kecuali jika persetujuan khusus telah diberikan atau terdapat kewajiban legal atau profesional untuk mengungkapkan informasi.

7) Prinsip Perilaku Profesional Kewajiban untuk menjauhi tingkah laku yang dapat mendiskreditkan profesi harus dipenuhi oleh anggota.

8) Prinsip Standar Teknis

Standar teknis dan standar profesional yang harus ditaati anggota adalah standar yang dikeluarkan oleh Ikatan Akuntan Indonesia, International Federation of accountan, badan pengatur, dan peraturan perundang-undang yang relavan.

\section{Tujuan Kode Etik}

Tujuan kode etik profesional adalah menuntut akuntan untuk memelihara sikap profesional. Kode etik dibentuk dengan tujuan untuk memberikan profesi kepada para pemakai jasa akuntan dan sesama 
rekan akuntan publik dengan jalan mengatur tingkah laku para akuntan yang berpraktik. Kode etik bukan saja berlaku sebagai pernyataan tanggung jawab tetapi juga merupakan alat atau pedoman dalam menjalankan praktik sebagai akuntan. Para akuntan harus memahami bahwa jasa akuntan tidak akan ada harganya bila masyarakat tidak percaya pada hasil kerja akuntan.

\section{Profesi Akuntan Indonesia}

Menurut

Internasional

Federation of Accountants (dalam Aprilyan, 2011) yang dimaksud dengan profesi akuntan adalah semua bidang pekerjaan yang mempergunakan keahlian dibidang akuntansi. Bidang pekerjaan akuntan dapat dibagi menjadi 4 golongan, yaitu: akuntan publik, akuntan perusahan, akuntan pendidik, dan akuntan pemerintah.

\section{Pengakuan Profesional}

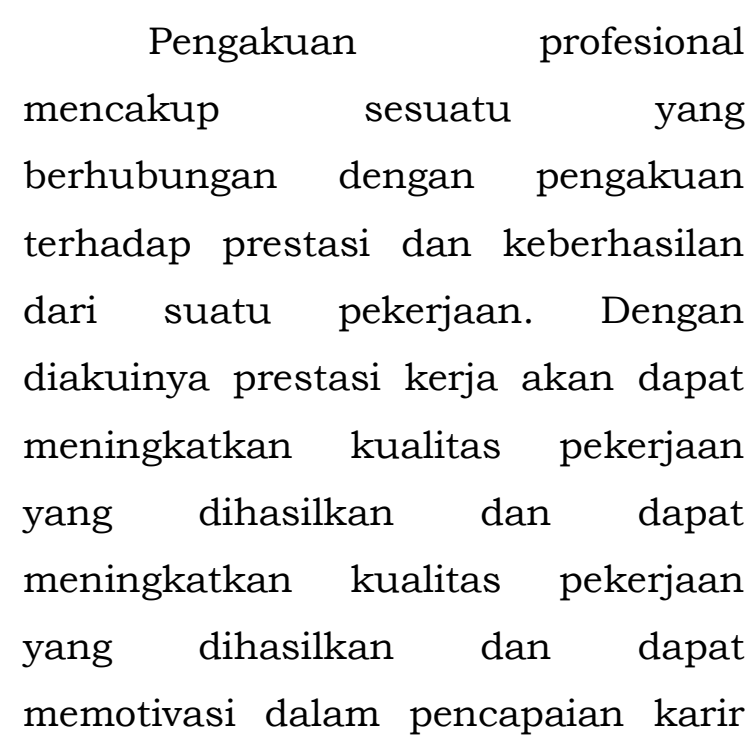

yang lebih baik. Faktor ini dapat meningkatkan dan menumbuhkan perkembangan perusahan atau individu sendiri (Andrianti dalam Astuti, 2014).

\section{Hipotesis Penelitian}

Pemahaman Mahasiswa mengenai Kode Etik Profesi

Teori etika merupakan teori yang membantu manusia untuk mengambil keputusan moral dan menyediakan pembuktian mengenai fakta yang mendukung mengenai pengambilan keputusan (Bertens dalam Januarti, 2011). Dengan teori etika calon akuntan dapat bertindak sesuai dengan moral dan mengambil keputusan sesuai dengan pedoman profesi yaitu kode etik akuntan. Berdasarkan uraian di atas dapat dirumuskan hipotesis pertama sebagai berikut:

H1: Pemahaman kode etik profesi berpengaruh positif terhadap pemilihan karir sebagai akuntan.

Pengakuan Profesional Memoderasi Hubungan Pemahaman Kode Etik Profesi dan Pemilihan Karir Sebagai Akuntan

Menurut teori kepribadian yang dikemukakan oleh Noviyanti (2008,) kepribadian merupakan caracara unik yang ditempuh individu 
dalam bereaksi dan berinteraksi dengan orang lain. Dalam pemilihan profesi akuntan tidak hanya pemahaman mengenai kode etik, namun terdapat faktor lain yang dapat mempengaruhi minat mahasiswa dalam memilih profesinya. Salah satu faktor yang menjadi pertimbangan adalah pengakuan profesional. sebagai bentuk penghargaan terhadap prestasi dan keberhasilan dari suatu pekerjan. Sehingga hipotesis kedua dapat digambarkan sebagai berikut:

H2: Pengakuan profesional memoderasi hubungan pemahaman kode etik profesi dan pemilihan karir sebagai akuntan.

\section{METODE PENELITIAN}

\section{Kerangka Pemikiran}

Kerangka pemikiran yang dibuat berupa gambaran skema untuk lebih menjelaskan mengenai hubungan antara variabel yang diuji.

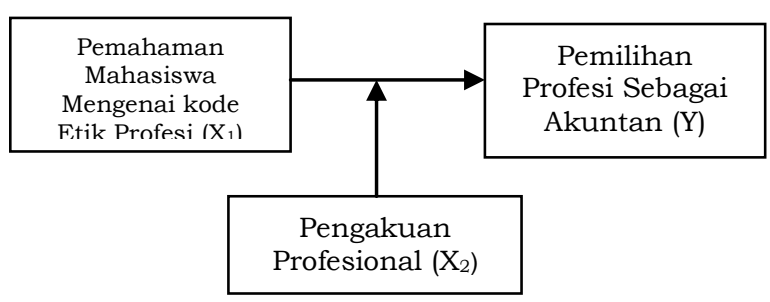

Gambar 1. Kerangka Penelitian

\section{Lokasi Penelitian dan sampel}

Lokasi penelitian ini bertempat di Universitas Udayana, Denpasar, Program Pasca Sarjana Magister Akuntansi. Sampel dalam penelitian ini adalah mahasiswa yang sedang mengikuti Program Pasca Sarjana Magister Akuntansi di Universitas Undayana, Denpasar yang berjumlah 95 orang.

\section{Jenis Data}

Jenis data yang digunakan dalam penelitian ini adalah kuantitatif. Metode kuantitatif adalah metode penelitian yang berlandaskan pada filsafat postivisme, digunakan untuk meneliti pada sampel tertentu, pengumpulan data menggunakan instrumen penelitian, analisis data bersifat kuantitatif/statistik, dengan tujuan untuk menguji hipotesis yang telah ditetapkan (Sugiyono:2017)

\section{Sumber Data}

Sumber data digunakan dalam penelitian ini adalah data primer. Menurut Ibrahim (2015:69) data primer adalah data yang diperoleh secara langsung yang bersumber dari jawaban kuisioner dari responden yang diinginkan dalam penelitian.

\section{Teknik Pengumpulan Data}

Penelitian ini menggunakan teknik pengumpulan data dengan menyebar kuesioner (angket) pada 
mahasiswa Pasca Sarjana Magister Akuntansi Universitas Udayana Denpasar. Kuesioner merupakan teknik pengumpulan data yang dilakukan dengan cara memberi seperangkat pertanyaan atau pertanyaan tertulis pada responden untuk dijawab (Sugiyono:2017). Kuesioner yang telah disebar akan diukur dengan Skala Likert. Skala likert digunakan untuk mengukur sikap, pendapat, dan persepsi seorangatau sekelompok orang tentang fenomena sosial (Sugiyono:2017).

\section{Instrumen}

\section{Penelitian}

dan

\section{Pengujiannya}

\section{Pengujian Validitas}

Menurut Prityano, (2010) uji validasi adalah pengujian yang dilakukan guna untuk mengetahui seberapa cermat suatu instrumen dalam mengukur apa yang ingin diukur. Metode pengambilan keputusan pada uji validitas biasanya ada dua model yaitu menggunakan batasan $r$ tabel dengan signifikansi 0,05 dan uji 2 sisi, atau mengguanakan batasan 0,3 .

1. Jika $r=0.30$ atau diatas 0.30, maka item-item dari pertanyaan kuisioner adalah valid

2. Jika $r \neq 0.30$ atau dibawah 0.30 , maka item-item dari pertanyaan kuisioner tidak valid.
Pengujian Reliabilitas

Reliabilitas menunjukkan sejauh mana suatau hasil penguukuran terhadap aspek yang sama pada alat ukur yang sama. Reliabilitas kuisioner menunjukkan pada suatu pengertian bahwa instrumen cukup dapat dipercaya untuk digunakan sebagai alat ukur menunjukkan ketepatan, kemantapan suatu alat ukur yang baik, dalam hal ini kuisioner harus berisi pertanyaanpertanyaan yang jelas sehingga hasilnya memang benar-benar sesuai kenyataan. Uji reliabilitas dilakukan dengan metode internal concistency. Reliabilitas instrument penelitian dalam penelitian ini diuji dengan koefisien cronbach's Alpha. Jika nilai koefisien alpha lebih besar dari 0.6 maka disimpulkan bahwa instrument penelitian tersebut handal atau reliable (Sugiyono:2017).

\section{Teknik Analisis Data}

Analisis data dalam penelitian ini menggunakan model analisis regresi linier berganda (Multiple Linear Regression Analysis). Model analisis regresi linier berganda adalah analisis untuk mengetahui hubungan antara variabel independen dengan variabel dependen dengan persamaan linear. Analisis data diolah dengan menggunakan bantuan program SPSS 
(Statistical Product and Service Solution).

\section{Pengujian Asumsi Klasik}

Uji Normalitas

Uji normalitas dilakukan untuk mengetahui apakah data terdistribusi normal atau tidak. Analisi parametrik seperti regresi linier mensyaratkan bahwa data harus terdistribusi dengan normal. Uji normalitas pada regresi bisa menggunakan beberapa metode, antara lain yaitu dengan metode Kolmogorov-Srninov Z untuk menguji normalitas data masingmasing variabel dan metode Nomal Probability Plots (Priyatno:2010).

\section{Uji Multikolinearitas}

Uji multikolinearitas bertujuan untuk menguji apakah model regresi ditemukan adanya kolerasi antar variabel bebas. Dengan kata lain, tidak terjadi multikolinearitas. Model regresi yang bebas dari multikolinearitas adalah yang memiliki nilai Variance Inflation Factor $(V I P) \leq 10$ dan mempunyai angka kolerasi $\geq 10 \%$ (Ghozali, 2009:96).

\section{Uji Heterokedastisitas}

Uji heterokedastisitas adalah kedaan dimana terjadinya ketidaksamaan varian dari residual pada model regresi. Model regresi yang baik mensyaratkan tidak adanya masalah heterosdasitisitas. Untuk mendektesi ada tidaknya heterokedastisitas ada beberapa metode, antara lain dengan cara uji Spearman's rho, uji Park, uji Glejser, dan dengan melihat pola titik-titik pada scatterplots regresi (Priyatno, 2010).

\section{Uji Hipotesis}

Koefisien Determinasi

Menurut Wirawan (2014), koefisien determinasi menunjukkan porsi (persentase) variasi variabel terikat Y yang dapat dijelaskan oleh persamaan regresinya atau oleh persamaan regresinya atau oleh variasi variabel bebas $\mathrm{X}$. Dari rumus (10.18) dapat dimengerti bahwa $r^{2}$ tak pernah negatif dan besarnya antara 0 dan $1\left(0 \leq r^{2} \leq 1\right)$. Jika semua titik terletak tepat pada garis regresi sampel maka $\mathrm{r}^{2}=1$, dalam hal ini dikatakan sesuai secara sempurna (perfect fit). Yang, juga berarti 100 persen total variasi variabel terikat dapat dijelaskan oleh variabel bebasnya. Jika $\mathrm{r}^{2}=0$, berarti tidak ada total variasi variabel terikat $\mathrm{Y}$ yang dapat dijelaskan ole variasi variabel bebas $\mathrm{X}$.

Analisis Uji Interaksi Variabel Moderating

Penelitian ini melakukan uji interaksi untuk menguji variable moderating yang berupa etika auditor dengan menggunakan Moderated Regression Anlyisis (MRA). MRA 
merupakan aplikasi khusus regresi linier berganda, dimana dalam persamaan regresinya mengandung unsur interaksi (perkalian dua atau lebih variabel independen). Uji interaksi ini digunakan untuk mengetahui sejauh mana interaksi variabel pengakuan profesional dapat mempengaruhi pemahaman Mahasiswa pada pemilihan profesi akuntan. Model persamaan MRA yang digunakan:

$\mathrm{Y}=\mathrm{a}+\mathrm{b}_{1} \mathrm{X}_{1}+\mathrm{b}_{2} \mathrm{X}_{2}+\mathrm{b}_{3} \mathrm{X}_{1} \mathrm{X}_{2}+\mathrm{e}$

Dimana :

$\mathrm{Y}=$ pemilihan profesi akuntan

$\mathrm{a}=$ konstanta

$\mathrm{b}=$ koefisien regresi

$\mathrm{X} 1$ = variabel pemahaman kode etik

$\mathrm{X} 2$ = variabel pengakuan professional

\section{Uji Parsial (Uji t)}

Menurut Priyatno (2010) uji t adalah uji yang digunakan untuk mengetahui signifikan pengaruh variabel bebas secara parsial terhadap variabel terikat.Cara pengujiannya sebagai berikut:

1) Probabilitas < taraf signifikan 5\% maka HO ditolak dan $\mathrm{Ha}$ diterimaartinya terdapat pengaruh signifikan antara variabel bebas secara parsial (individual) terhadap variabel terikatnya.

2) Probabilitas > taraf signifikan 5\% maka HO diterima dan Ha ditolak artinya tidak terdapat pengaruh signifikan antara variabel bebas secara parsial (individual) terhadap variabel terikatnya.

\section{Uji Simultan (Uji F)}

Menurut Priyatno (2010) uji F digunakan untuk mengetahui seberapa besar pengaruh antara variabel bebas secara bersama-sama terhadap variabel terikat. Cara pengujiannya sebagai berikut:

1) Probabilitas < taraf signifikan 5\% maka HO ditolak dan Ha diterima artinyaterdapat pengaruh signifikan antara semua variabel bebas secarasimultan/bersama terhadap variabel terikatnya.

2) Probabilitas > taraf signifikan 5\% maka HO diterima dan Ha ditolak artinya tidak terdapat pengaruh signifikan antara semua variabel bebas secara simultan/bersama terhadap variabel terikatnya.

\section{HASIL DAN PEMBAHASAN}

Hasil pengujian menunjukkan bahwa instrument yang digunakan dalam penelitian ini telah valid ( $r$ hitung > 0,3) dan reliabel (besaran Cronbach's Alpha > 0,6). Demikian pula, uji asumsi klasik menghasilkan temuan bahwa model penelitian yang diajukan telah memenuhi kriteria pengujian asumsi klasik secara memadai. 
Hasil Pengujian Hipotesis

Koefisien Determinasi

Pada uji ini digunakan nilai Adjusted $\mathrm{R}^{2}$, dimana nilai Adjusted $\mathrm{R}^{2}$ dapat naik atau turun apabila satu variabel bebas ditambahkan ke dalam model. Berdasarkan tabel 1 ditunjukkan bahwa hasil analisis koefisien determinasi dapat terlihat dari Adjusted R Square sebesar 0,524.
Hal ini mengindikasikan bahwa kontribusi variabel pemahaman kode etik sebesar 0,524 yang berarti besar pengaruh variabel bebas terhadap variabel terikatnya adalah $0,524 \mathrm{x}$ $100 \%=52,4 \%$, sedangkan sebesar $47,6 \%$ dijelaskan oleh faktor-faktor lainnya yang tidak diuji dalam penelitian ini.

Tabel 1 Hasil Analisis Koefisien Determinasi X1 terhadap Y

\begin{tabular}{lcccc} 
Model & $R$ & \multicolumn{2}{c}{$R$ Square } & Adjusted $R$ Square Std. Error of the Estimate \\
\hline 1 & $0,727^{\text {a }}$ & 0,529 & 0,524 & 1,153
\end{tabular}

a. Predictors: (Constant), $\mathrm{X} 1$

Pada uji ini digunakan nilai Adjusted $\mathrm{R}^{2}$, dimana nilai Adjusted $\mathrm{R}^{2}$ dapat naik atau turun apabila satu variabel bebas ditambahkan ke dalam model. Berdasarkan tabel ditujukkan bahwa hasil analisis koefisien determinasi dapat terlihat dari Adjusted $R$ Square sebesar 0,758. Hal ini mengindikasikan bahwa kontribusi variabel moderatingnya sebesar 0,758 yang berarti variabel pengakuan profesional memoderasi variabel bebas terhadap variabel terikatnya adalah $0,758 \times 100 \%=$ $75.8 \%$, sedangkan sebesar $24,2 \%$ dijelaskan oleh faktor-faktor lainnya yang tidak diuji dalam penelitian ini.

Tabe1 2 Hasil Analisis Koefisien Determinasi X1, X2, X1X2 terhadap Y

\begin{tabular}{lcccc} 
Model & $R$ & \multicolumn{2}{c}{$R$ Square } & Adjusted $R$ Square Std. Error of the Estimate \\
\hline 1 & $0,875^{\mathrm{a}}$ & 0,765 & 0,758 & 0,823
\end{tabular}

a. Predictors: (Constant), X1X2, X1, X2

\section{Analisis Uji Interaksi Variabel Moderating}

Berdasarkan hasil analisis regresi pada tabel dapat dilihat bahwa untuk variabel $\mathrm{X} 1$ diperoleh nilai signifikan 0,000 kurang dari 0,05 $(0,000<0,05)$ dan variabel X2 memiliki nilai signifikan 0,000 kurang 
dari 0,05 $(0,00<0,05)$, dan interaksi $\mathrm{X} 1$ dan X2 memiliki nilai signifikan 0,004 kurang dari $0,05(0,004<0,05)$ sehingga diperoleh model regresinya adalah sebagai berikut: $\mathrm{Y}=-0,103+$ $0,279 \mathrm{X}_{1}+0,626 \mathrm{X}_{2}+0,159 \mathrm{X}_{1} \mathrm{X}_{2}+$ 0,061

Tabel 3 Hasil Uji Interaksi Variabel Moderating

\begin{tabular}{|c|c|c|c|c|c|c|}
\hline & \multirow[t]{2}{*}{ Model } & \multicolumn{2}{|c|}{$\begin{array}{c}\text { Unstandardized } \\
\text { Coefficients }\end{array}$} & \multirow{2}{*}{$\begin{array}{c}\text { Standardized } \\
\text { Coefficients } \\
\text { Beta }\end{array}$} & \multirow[t]{2}{*}{$\mathrm{t}$} & \multirow[t]{2}{*}{ Sig. } \\
\hline & & B & Std. Error & & & \\
\hline \multirow[t]{4}{*}{1} & (Constant) & $-0,103$ & 0,061 & & $-1,680$ & 0,096 \\
\hline & Zscore (X1) & 0,279 & 0,069 & 0,279 & 4,041 & 0,000 \\
\hline & Zscore(X2) & 0,626 & 0,067 & 0,626 & 9,310 & 0,000 \\
\hline & $Z X 1 X 2$ & 0,159 & 0,053 & 0,157 & 2,985 & 0,004 \\
\hline
\end{tabular}

a. Dependent Variable: Zscore(Y)

\section{PEMBAHASAN}

Pemahaman Mahasiswa Mengenai Kode Etik Profesi terhadap Pemilihan Karir sebagai Akuntan.

Teori etika yang dikemukankan oleh Bertens dalam Januarti (2011) dijelaskan bahwa etika dapat membantu manusia untuk mengambil keputusan moral dan menyediakan pembuktian mengenai fakta yang mendukung pengambilan keputusan. Dengan teori etika calon akuntan dapat bertindak sesuai dengan moral dan mengambil keputusan sesuai dengan pedoman profesi akuntan yaitu kode etik. Berbagai kasus etika akan dapat dihindari jika setiap akuntan dan calon akuntan mempunyai pengetahuan, pemahaman dan dapat menerapkan etika secara memadai dalam melaksanakan tugasnya sebagai seorang akuntan yang profesional. Dengan sikap akuntan yang profesional maka akan mampu menghadapi tekanan yang muncul dari dirinya sendiri maupun dari pihak eksternal.

Menurut Mentayani dkk (2014), terdapat perbedaan persepsi antara mahasiswa akuntansi negeri dan swasta. Mahasiswa akuntansi negeri memiliki pemahaman menegenai kode etik yang lebih baik dibandingkan mahasiswa akuntansi swasta. Mencermati hal diatas, maka diperlukannya pengetahuan mengenai pemahaman mahasiswa jurusan akuntansi terhadap persoalan etika yang mungkin atau akan mereka hadapi, sehingga pemahaman dapat 
dipertimbangkan dalam pemilihan karir sebagai akuntan.

Berdasarkan hasil perhitungan analisis regresi liniear berganda dengan pengujian secara parsial diperoleh besar thitung variabel pemahaman mahasiswa mengenai kode etik profesi sebesar 2,79 dengan nilai sig $0,000<a(0,05)$ yang berarti penolakan $\mathrm{H}_{0}$ dan $\mathrm{H}_{1}$ diterima yaitu variabel pemahaman mahasiswa mengenai kode etik profesi berpengaruh positif terhadap pemilihan karir sebagai akuntan, dimana jika variabel pemahaman mahasiswa mengenai kode etik profesi meningkat sebesar 1 satuan akan terjadi peningkatan pemilihan profesi sebagai akuntan sebesar 0,279 satuan.

\section{Pengakuan Profesional Memoderasi} Hubungan Pemahaman Kode Etik Akuntan dan Pemilihan Karir Sebagai Akuntan

Menurut teori kepribadian yang dikemukakan oleh Noviyanti (2008) kepribadian merupakan caracara unik yang ditempuh individu dalam bereaksi dan berinteraksi dengan orang lain. Dalam pemilihan profesi akuntan tidak hanya pemaham mengenai kode etik, namun terdapat faktor lain yang dapat mempengaruhi minat mahasiswa dalam memilih profesinya. Salah satu faktor yang menjadi pertimbangan adalah pengakuan profesional. sebagai bentuk penghargaan terhadap prestasi dan keberhasilan dari suatu pekerjaan. Dengan adanya pengakuan profesional seseorang akan melakukan cara-cara yang unik untuk mendapatkan sebuah penghargaan prestasi kerja akan dapat meningkatkan kualitas pekerjaan yang dihasilkan dan dapat meningkatkan motivasi dalam pencapaian karir yang lebih baik. Faktor ini dapat meningkatkan dan menumbuhkan perkembangan perusahan dan individu. Menurut Widyasari (2010), adanya pengaruh pengakuan profesional terhadap pemilihan karir. Pengakuan profesional meliputi hal-hal yang berhubungan dengan pengakuan terhadap prestasi.

Berdasarkan hasil perhitungan analisis regresi liniear berganda dengan pengujian secara parsial diperoleh besar thitung variabel pemahaman mahasiswa mengenai kode etik profesi dan variabel pengakuan profesional sebesar 1,59 dengan nilai sig $0,004<a(0,05)$ yang berarti penolakan $\mathrm{H}_{0}$ dan $\mathrm{H}_{1}$ diterima yaitu pengakuan profesional memoderasi hubungan pemahaman mahasiswa terhadap kode etik profesi dan pemilihan profesi akuntan. Besar pengaruh pemahaman kode etik terhadap pemilihan profesi diperoleh 
sebesar 52,4\% sedangkan setelah dimoderasi oleh variabel pengakuan professional pengaruhnya menjadi meningkat yakni sebesar $75,8 \%$. Hal ini berarti bahwa variabel pengakuan profesional menguatkan hubungan antara pemahaman kode etik dan pemilihan profesi.

\section{KESIMPULAN, IMPLIKASI DAN KETERBATASAN PENELITIAN}

\section{Simpulan}

Berdasarkan hasil analisis data dan pembahasan pada bab sebelumnya, maka dapat ditarik kesimpulan bahwa:

1) Pemahaman mahasiswa akuntansi mengenai kode etik profesi berpengaruh positif terhadap pemilihan karir sebagai akuntan. Hal ini berarti apabila pemahaman kode etik semakin baik maka mengakibatkan pemilihan karir sebagai akuntan semakin baik pula.

2) Pengakuan profesional memoderasi hubungan pemahaman mahasiswa mengenai kode etik profesi terhadap pemilihan karir sebagai akuntan.

\section{Keterbatasan Penelitian}

Dari simpulan diatas maka peneliti masih terdapat beberapa keterbatasan dari hasil penelitian ini, sebagai berikut:
1) Penelitian ini hanya menggunakan sampel mahasiswa program pasca sarjana magister akuntansi saja. Peneliti selanjutnya dapat memperluas dengan menggunakan mahasiswa program pendidikan profesi akuntansi ataupun akuntan publik, akuntan pemerintah, akuntan manajemen.

2) Untuk penelitian selanjutnya dapat menggunakan variabel lain yang berkaitan dengan aspek keperilakuan bagi profesi akuntan. Sehingga dapat memberikan kontribusibagi profesi akuntan serta ilmu akuntansi keperilakuan.

3) Penelitian ini hanya menggunakan objek pada satu institusi saja, disarankan bagi peneliti selanjutnya dapat menggunakan beberapa institusi dengan lokasi yang berbeda.

\section{REFERENSI}

Andersen, Wiliam. 2012. Analisis Persepsi Mahasiswa Akuntansi Dalam Memilih Profesi Sebagai Akuntan (Studi Empiris pada Mahasiswa Akuntansi UNDIP,UNIKA, UNNES, UNISSULA, UDINUS, UNISBANK, STIE TOTALWin dan Mahasiswa PPA UNDIP). Skripsi. Universitas Diponegoro.

Aprilyan, Laraabrasa. 2011. FaktorFaktor Yang Mempengaruhi 
Mahasiswa Akunttansi Dalam Pemilihan Karir Menjadi Akuntan (Studi Empiris Pada Mahasisa UNDIP dann Mahasiswa Akuntansi UNIKA). Skripsi. Universitas Diponegoro.

Astuti, Anita. 2014. Faktor-Faktor Yang Mempengaruhi Mahasiswa Akuntansi Dalam Memilih Karir Sebagai Akuntan Publik Pada Mahasiswa Akuntansi Universitas Kristen Satya Wacana Salatiga. Sripsi. Universitas Kristen Satya Wacana Salatiga.

Bertens, K. 2000. Pengantar Etika Bisnis. Penerbit Kanisius, Yogyakarta.

Duska, Ronald, F., dan Btenda,S. 2003. Accounting Ethics. Blackwell Publishing Ltd.

Graham, Gordom. 2014. Teori-Teori Etika. Bandung. Nusa Media

Ghozali, Imam. 2009. Aplikasi Analisis Multivariate dengan Program SPS. Edisi Kedua. Semarang. Universitas Diponegoro.

Harahap, Sofyan S. 2011. Etika Bisnis dalam Perspektif Islam. Jakarta. Salemba Empat.

Halim, Abdul. 2015. Auditing DasarDasar Audit Laporan Keuangan. Yogyakarta. UPP STIM YKPN.

Hunt, S. D. dan S. J. Vite11. 1986. "A General Theory of Marketing Ethics Journal of Macromarketing Spring pp. 5-16.

Ibrahim. 2015. Metedologi Penelitian Kualitatif. Bandung. Alfabeta.

Institut Akuntan Publik Indonesia. 2011. Standar Profesional Akuntan Publik. Jakarta. Salemba Empat.
Institut Akuntan Publik Indonesia. 2008. Kode Etik Profesi Akuntan Publik. Jakarta. Salemba Empat.

Jusup, AL. H. 2014. Auditing Pengauditan Berbasis ISA Edisi 2. Yogyakarta. Stie Ykpn.

Jamnik, Anton. 2011. Ethical Code In The Public Accounting Profession. Slovenia. Theologi Faculty Of University In Ljubljna.

Januarti, Indira. 2011. Analisis Pengaruh Auditor, Komitmen Profesional, Orientasi Etis dan Nilai Etika Orrganisasi Terhadap Persepsi dan Pertimbangan Etis. Banda Aceh. Universitas Diponogoro.

Mulyadi. 2014. Auditing.Jakarta. Salemba Empat.

Nurlan, Andibasse. 2011. Persepsi Akuntan Dan Mahasiswwa Jurusan Akuntansi Terhadap Kode Etik Ikatan Akuntansi Indonesia. Skripsi. Universitas Hasanuddin.

Noviyanti, Suzy. 2008. Skeptisme Profesional Auditor dalam mendeteksi Kecurangan. Salatiga. Unversitas Kristen Satya Wacana.

Pamela, Astriana. 2014. Pengaruh Pemahaman Kode Etik Profesi Terhadap Perilaku Etis Mahasiswa Akuntansi Universitas Negeri Yogyakarta. Skripsi. Universitas Negeri Yogyakarta.

Priyatno, D., 2010. Teknik mudah dan Cepat Melakukan Analisis Data Penelitian dengan SPSS. Yogyakarta. Gava Media

Sugiyono. 2017. Metode Penelitian Pendidikan Pendekatan 
Kuantitatif Kualitatif dan R\&D. Bandung. Alfabeta.

Samryn, L.M. 2012. Akuntansi Manajemen. Jakarta. Kencana Prenademedia Group.

Sudarmita. 2013. Etika Umum Kajian Tentang Beberapa Masalah Pokok dan teori Etika Normatif. Yogyakarta. Kanisus
Widyasari, Yuanita. 2010. Persepsi Mahasiswa Akuntansi Mengenai Faktor-Faktor Yang Membedakan Pemilihan Karir. Skripsi. Universitas Diponegoro.

Wirawan, Nata. 2014. Cara Mudah Memahami Statistika Ekonomi Dan Bisnis. Denpasar. Keraras Emas. 